\title{
Sobre o conceito de Comunidade Surda*
}

\section{Hildo Honório do Couto Universidade de Brasília}

\section{Abstract}

The main objective of this article is to show that in order to appropriately understand the current concept of deaf community it is necessary to make a distinction between language community (communauté de langue) and speech community (communauté de parole) in consideration. Since the language community of the deaf is scattered among the territory of the community of the hearing, what really matters for the deaf in general is the speech community, i. e., the societies, clubs and similar organizations where the individual can meet with his peers and talk about whatever comes to mind. The most fundamental feature of the deaf speech community is its own sign language. It is in this speech community that the deaf find themselves at ease. It is there that they can effectively manifest their identity. 


\section{INTRODUÇÃO}

$\mathrm{N}$

os últimos anos, vem surgindo o conceito de comunidade, sobretudo sob o rótulo de Ecologia Fundamental da Língua (EFL). De acordo com ele, para que haja uma língua (L) é preciso que exista uma população (P) que a tenha formado e que a use, sendo que essa P só pode existir se houver um território (T), no qual possa viver e conviver. É o que está esquematizado na figura 1.

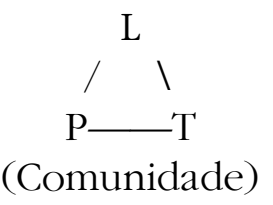

FIGURA 1 - Ecologia Fundamental da Língua

Como se pode ver, a EFL é chamada também de comunidade, e é, sincronicamente, o ecossistema imediato em que a língua está inserida, o que significa que toda língua tem que se enquadrar nele. No entanto, tem-se objetado que a língua dos ciganos (romani), o hebraico, o esperanto e as línguas de sinais (ou gestuais), entre algumas outras, refutariam essa tese, uma vez que o conjunto de falantes $(\mathrm{P})$ de nenhuma delas teria um T próprio. Pelo contrário, os usuários dessas línguas se dispersariam pelo T dos falantes de outras línguas. O romani, o hebraico e as línguas de sinais pelo menos são línguas naturais. O esperanto nem isso é, ou seja, é uma língua artificial. Por língua natural, entendo aquela língua que surge espontaneamente, tendo como objetivo ser um meio para os atos de interação comunicativa entre um grupo de pessoas que se estabelecem em determinado território. É o caso do tupi, do catalão, do inuit e dos crioulos (COUTO, 1996), além da língua de sinais. Língua não- 
natural, ou seja, língua artificial é aquela que é fabricada por um indivíduo ou grupo de indivíduos, como é o caso do esperanto, do volapük, da interlíngua e de muitas outras. Existe a possibilidade de uma língua artificial, como o esperanto, tornar-se língua natural mediante a sua aquisição como língua materna por um grupo de pessoas. Mas isso não será examinado aqui.

Há outros critérios para se considerar um meio de comunicação como uma língua natural. Um deles é o de que a língua seja falada por uma comunidade. Um outro exige que haja pelo menos um falante nativo dessa língua (BEHARES, 1999, p. 131, reportando-se a Stokoe). Como se vê, a problemática é a mesma que existe no caso das línguas crioulas. Alguns especialistas dessa área consideram que há crioulização quando um grupo de crianças adquire um pidgin ou jargão inicial como língua nativa. Outros acham que se tem um crioulo sempre que esse pidgin/jargão inicial passa a ser a língua principal de uma comunidade (COUTO, 1996, 2002a).

O conceito de comunidade lingüística vem sendo discutido por diversos autores, há muito tempo, como é o caso de Bloomfield (1933). Eu mesmo me dediquei ao assunto, embora sob a perspectiva da distinção entre comunidade de língua (CL) e comunidade de fala (CF). Como veremos, os primeiros autores a falar sobre esse assunto misturavam as duas.

O objetivo principal deste artigo é demonstrar que, subdividindo comunidade (EFL) em comunidade de língua e comunidade de fala, podemos explicar a situação especial das línguas mencionadas no início desta Introdução, especialmente a das línguas de sinais, bem como a de outras. Para atingir esse fim, será necessário discutir detalhadamente o que se entende por Ecologia Fundamental da Língua, bem como explicitar o que é comunidade e seus sub-ramos, comunidade de língua e comunidade de fala.

Como se pode ver no nome do modelo da figura 1, a abordagem é ecológica, ou melhor, ecolingüística, uma vez que usa conceitos da ecologia biológica, como o fazem Fill (1993), Mufwene (2001), Mühlhäusler (2003) e outros mencionados nas Referências 
Bibliográficas. Como sabemos, a categoria mais central da ecologia biológica é a de ecossistema, ou seja, as relações entre os seres vivos (vegetais, microorganismos e animais) e o meio ambiente em que vivem. Ele é um sistema integrado e autofuncionante. Sabemos também que ele varia muito de tamanho, podendo ir desde o ecossistema do universo, passando pelo da terra até o de um tanque ou menos ainda. Enfim, o ecossistema é definido pelo pesquisador. Essa característica epistemológica é muito importante para o estudo das comunidades lingüísticas, pois, como veremos, elas são porosas, não têm fronteiras claramente definidas. Geralmente, o investigador tem que fazer um corte na realidade e definir sua área de estudo exatamente como faz o ecólogo.

Vejamos como este texto está estruturado.

Na seção 2, abordo a Ecologia Fundamental da Língua, inclusive filiando-a historicamente. Veremos que a idéia em si é muito simples. Ela é tão simples que muitos autores não a considera(ra)m digna de ser discutida. Na seção 3, trato da subdivisão da EFL (comunidade) em comunidade de língua e comunidade de fala, salientando como isso pode explicar o caso especial das comunidades dos surdos. Na seção 4, discuto especificamente o conceito de comunidade de surdos. Na seção 5, faço uma abordagem da comunidade como base para a identidade individual. Na seção 6, por fim, tento tirar algumas conclusões de toda a discussão precedente.

\section{A ECOLOGIA FUNDAMENTAL DA LÍNGUA}

Vimos que a Ecologia Fundamental da Língua (EFL) afirma que uma língua (L) só existe e subsiste se houver uma população (P) que a tenha formado e que a use. Afirma ainda que essa população só existe como tal se conviver em determinado território (T). Embora a quase totalidade dos lingüistas não falem sobre esse conceito, a idéia em si é muito antiga. Por exemplo, Morgan (1878, p. 102, 112-121) afirmou, falando dos índios iroqueses, que "cada tribo era individualizada por um nome, um dialeto separado, um governo 
supremo e a posse de um território que ela ocupava e defendia como seus próprios". Segundo Tonneau (1934, p. 115), "o homem real não é uma entidade abstrata. Para conhecer a realidade de sua vida econômica, nós o estudaremos no meio concreto em que ela se desenrola. Com isso, deve-se levar em consideração o meio natural, a população e os quadros institucionais". Embora o autor tenha falado em termos econômicos, seu modelo pode perfeitamente ser traduzido em termos lingüísticos. Nesse caso, o seu meio natural equivale a T, população a $\mathrm{P}$ e quadros institucionais a L. Isso é o todo que constitui a comunidade, ou seja, a EFL.

O conceito de EFL foi proposto pela primeira vez em Couto (1999, seção 7.1). Posteriormente, ele foi retomado em Couto (2000), logo depois em Couto \& Silva (2001), bem como em Couto (2002a, b, c). Em todos esses textos, salientei a idéia de que, pelo menos dos pontos de vista genético e evolutivo, tudo na língua tem a ver com as relações entre os três componentes da Ecologia Fundamental da Língua, ou seja, entre P, T e L. No presente texto, essas relações não serão analisadas em detalhe. No momento, o mais importe é lembrar que comunidade (EFL) é o ecossistema imediato e maior de que a língua faz parte. Tanto que o mais adequado seria falar-se em Ecossistema Fundamental da Língua, sutileza terminológica que não prejudica em nada a tese, mesmo porque a sigla para ambas expressões é a mesma (EFL).

O termo "fundamental" que ocorre na expressão Ecologia Fundamental da Língua tem a ver com fundação, tanto no sentido de "ato de fundar", como faz Mufwene (2001), como no de "base" de um edifício, por exemplo. No primeiro caso, reporta-se ao momento inicial de formação (fundação) da língua e da comunidade que a engloba. Portanto, a sigla EFL pode ser lida também como "Ecologia Fundacional da Língua". É esse ecossistema que fornece a base em que a língua se constrói e é usada. Conclui-se, portanto, que toda língua natural tem que se enquadrar na EFL. Se lhe falta um dos seus três pilares, ela será uma língua que não estará de acordo com o protótipo lingüístico, mas uma língua de algum modo 
atípica. Tanto que, no momento de sua "fundação", ou seja, de sua emergência, e nos momentos imediatamente subseqüentes, toda língua natural se enquadra rigidamente na EFL, é língua prototípica. São as vicissitudes históricas supervenientes que perturbam essa situação original, ou fundacional, fazendo dela uma língua atípica.

É o que aconteceu com o hebraico e com o romani. Adversidades históricas arrancaram o povo judeu e o povo cigano, respectivamente, de seu território original, provocando a diáspora e tornando-os portadores de línguas atípicas, no sentido de que não têm um $T$ próprio. Os judeus se espalharam por diversas partes do mundo, tendo desenvolvido variedades mistas das línguas do país hospedeiro: o judeu-espanhol na Península Ibérica e o iídiche na Europa Central e do Leste. O hebraico original ficou apenas com os sábios e filólogos. Por um golpe da sorte, o estado de Israel foi fundado e a língua ensinada às crianças, o que fez com que sua EFL fosse ressuscitada, a despeito dos problemas que isso possa ter causado aos palestinos.

Os ciganos não tiveram a mesma sorte. A partir do século XVIII, descobriu-se, mediante análise lingüística comparativa, que eles devem ter provindo da região central do norte da Índia, há quase mil anos. Essa região já foi o T de sua EFL. Só que, hoje em dia, nenhum cigano tem memória desse fato, o que não significa que não tenham tido seu $\mathrm{T}$ e, portanto, sua língua não tenha sido uma língua prototípica algum dia. Pelo estudo lingüístico, descobriu-se que passaram pelo Paquistão e Afeganistão, pela Pérsia, Turquia, Armênia e Grécia, tendo se instalado na Europa do Leste. Logo em seguida, foram migrando para o oeste da Europa, tendo chegado à Península Ibérica. Nesse instante, já havia incursões para a América, de modo que, por volta de 1520, já havia ciganos no Brasil (COUTO, 2002a).

O caso do esperanto é bem mais complicado. Vimos que ele não é uma língua natural, entre outras razões por não ter um $T$ próprio, embora aqui ou ali ele possa estar se naturalizando (adquirindo falantes nativos). O normal é seus usuários (P) se dispersarem por diversos países do mundo. Conclui-se, portanto, 
que, além de artificial, é uma língua atípica, como definida anteriormente. A despeito do fato de toda língua artificial ser forjada com base em línguas naturais já existentes, além da faculdade de linguagem de seu criador, ela não tem um T nem um $\mathrm{P}$ próprios. Isso significa que ela é duplamente atípica. Parece que fica pairando no ar.

Por fim, temos o caso das línguas de sinais (gestuais) dos surdos. Seja lá como tenha sido sua gênese, elas são línguas naturais. São manifestação da capacidade humana para a linguagem, além de serem usadas como L1 por uma parcela considerável de indivíduos. No entanto, às vezes se alega que não seriam línguas prototípicas, pois não se enquadrariam perfeitamente na EFL. Faltar-lhes-ia um T próprio. Os indivíduos surdos (P) se dispersariam pelo território da língua dos ouvintes. Peng (1981, p. 389) diz que "os surdos não vivem em uma comunidade no interior da comunidade maior, mas se espalham pelo meio da população ouvinte, freqüentemente isolados, ou só ocasionalmente em contato com outras pessoas surdas". Mottez (1992, p. 6) vai mais longe, afirmando que "os surdos formam um povo sem território. Seus clubes [...] tomam o lugar dele". Afirma também que "os banquetes são também seu território". Após discutirmos a distinção entre comunidade de língua e comunidade de fala, na seção seguinte, veremos que as línguas de sinais são como qualquer outra língua, inclusive no sentido de atender ao requisito da EFL. Os argumentos em sentido contrário não têm consistência porque partem apenas da comunidade de língua, ignorando, portanto, a comunidade de fala.

O L de EFL não equivale apenas a língua. Como os "quadros institucionais" de Tonneau dão a entender, esse L está para o conjunto de todas as linguagens da comunidade, do qual se tem um inventário parcial em Eco (1974, p. 392-413). A língua seria apenas uma dessas linguagens, motivo pelo qual se deveria representá-la por 1 minúsculo. Mas trata-se de um detalhe que não afeta a argumentação. Em um tratado de semiótica, talvez seja necessário discernir as duas coisas.

O L maiúsculo tem sido equiparado à cultura da comunidade. Mas língua e cultura não são a mesma coisa. O surdo nato compartilha 
com sua família todo um conjunto de dados culturais. No entanto, ele não fala nem ouve a língua que sua família usa, pelo menos não como os membros dela o fazem. Quando ele aprende essa língua, aprende-a apenas como L2, em geral na variedade escrita. Mesmo que seja treinado para vocalizá-la, isso é muito penoso para ele, por não poder monitorar os sons que está produzindo, ouvindo-os simultaneamente. Daí, freqüentemente, sua fala parecer fala sintetizada (ALMEIDA, 2002).

Gostaria de repetir que sempre que faltar um dos ângulos do triângulo da EFL, ou seja, sempre que faltar $\mathrm{P}$, ou T, ou L, não se terá uma língua prototípica. Peng (1981, p. 389-390) relata, reportandose a Rolf Kuschel, o caso do surdo chamado Kangobai, da ilha de Rennel do Pacífico Sul, que desenvolveu um conjunto de sinais individuais. Como não havia mais ninguém com quem ele pudesse compartilhar esses sinais, eles se perderam. Conforme deve ter ficado implícito, o P se compõe de uma série de indivíduos, representados por $\mathrm{p}_{\mathrm{x}}$, ou seja, $\mathrm{p}_{1}, \mathrm{p}_{2}, \mathrm{p}_{3}, \ldots, \mathrm{p}_{\mathrm{n}}$. No caso, só havia $\mathrm{p}_{1}$, o próprio Kangobai, o que significa que, ao fim e ao cabo, não havia P. Uma língua só emerge se houver pelo menos dois indivíduos para trocar atos de interação comunicativa, isto é, se houver pelo menos $\mathrm{p}_{1}$ e $\mathrm{p}_{2}$, o mínimo de que $\mathrm{P}$ pode ser formado.

\section{COMUNIDADE DE LÍNGUA E COMUNIDADE DE FALA}

Em linguagem comum, o termo "comunidade" tem pelo menos três acepções. A primeira é a de algo comum; a segunda, a de um grupo de pessoas que têm algo em comum; a terceira, a da EFL. Só vamos tratar dessa última. Mas, mesmo nesse sentido, ele tem se referido a mais de uma coisa, ou a mais de um aspecto da mesma coisa. Em todos os autores que trataram do assunto, e que estão alinhados na bibliografia, o termo fica ambíguo. Nenhum deles traçou uma distinção clara entre comunidade de língua (CL) e comunidade de fala (CF), sem a qual é difícil explicar a situação de muitas línguas do mundo. A especialista em línguas de sinais, Patricia 
Siple, por exemplo, afirmou que "há tantas línguas de sinais distintas quantas forem as comunidades surdas" (SIPLE, 1978, p. 5). No caso, ela estava se referindo ao que chamaremos aqui de comunidade de língua. Por outro lado, a referência de Newport (1999, p. 162), transcrita na seção 4, refere-se a comunidade de fala. Provavelmente, nenhuma das autoras estava consciente desse fato. Na presente seção, pretendo justamente traçar a distinção entre CL e CF.

A distinção foi proposta pela primeira vez em Couto (1990), tendo por base idéias contidas em Bloomfield (1933), Gumperz (1972), Labov (1980) e outros. Em Couto (1991, 1994) e Couto (1999), ela foi retomada e pormenorizada. Como se pode ver, CL e CF evocam a distinção feita por Saussure (1973) entre língua (langue) e fala (parole). Outra fonte da distinção é o par de conceitos do inglês language community e speech community, que correspondem aproximadamente aos dois conceitos saussureanos, nessa ordem. Por fim, temos os conceitos alemães de Sprachgemeinschaft e Sprechgemeinschaft. O primeiro tem por base a palavra Sprache (língua), e o segundo a palavra sprechen (falar). Quanto a Gemeinschaft, significa justamente comunidade. Mas, ainda no alemão, existem duas expressões que têm a ver diretamente com CF. Trata-se de Interaktionsgemeinschaft, que significa literalmente "comunidade de interação", e de Kommunikationsgemeinschaft, que significa, também literalmente, "comunidade de comunicação". Uma vantagem das duas últimas expressões alemãs é que enfatizam a idéia de que o que caracteriza uma CF é a interação concreta entre indivíduos. O importante é que as bases para a distinção entre CL e CF estavam estabelecidas.

Os dois conceitos têm equivalentes até na própria ecologia, como se pode ver no comentário de Bastardas i Boadas (2002). A "comunidade biológica" é o conjunto de seres vivos de diferentes espécies que compartilham uma mesma região. Portanto, equivale à CF complexa. A CF simples equivale mais à "população biológica", que é o conjunto de seres vivos da mesma espécie que vivem em determinado espaço. Aparentemente, o equivalente ecológico de CL seria a espécie, com o que Mufwene (2001) está inteiramente de acordo. 
CL é um conceito relativamente fácil de definir. É o domínio do que chamamos laicamente de língua. Assim, a CL portuguesa compreende Portugal, Brasil, Angola, Moçambique, Cabo Verde, Guiné-Bissau, São Tomé e Príncipe, Timor Loro Sae e outras regiões em que a língua portuguesa eventualmente seja usada. A CL islandesa se restringe à Islândia, enquanto a CL coreana compreende a Coréia do Norte e a Coréia do Sul. CL é o domínio do código, do sistema. Quando se fala em CL, pensa-se no domínio do sistema abstrato chamado língua, sobretudo a língua padrão.

A CF, por seu turno, é bem mais complexa. Voltando ao caso da Coréia, teríamos duas CFs, ou seja, a CF da Coréia do Sul e a CF Coréia do Norte. Por quê? Simplesmente porque os coreanos do norte interagem entre si muito mais do que com os coreanos do sul, a despeito do fato de falarem a mesma língua, isto é, de pertencerem à mesma CL. Por aí se vê que na definição de CF tem que entrar toda uma série de fatores adicionais, além de CL. A CL é uma condição necessária, mas não suficiente, para a existência de uma CF, mesmo porque em uma CF pode haver a participação de mais de uma CL.

O primeiro fator adicional que importa para a CF é a delimitação territorial, ou seja, a existência de um T próprio. Assim, a Guiana Francesa é uma CF independente da CF francesa, a despeito do fato de pertencer à mesma CL que a França. Do mesmo modo, o T da Coréia do Norte está claramente delimitado em relação ao da Coréia do Sul. Outros fatores seriam um sistema monetário próprio, forças armadas independentes, sistema viário, correios, sistema educacional, meios de comunicação de massa e assim por diante. Tudo isso faz com que a comunidade assim delimitada constitua um locus em que as pessoas interagem (comunicam-se) entre si intensamente, como já dão a entender as expressões alemãs Interaktionsgemeinschaft e Kommunikationsgemeinschaft.

Na França são falados o bretão, o basco, o catalão, o provençal, o alemão e outras variedades menores, além do francês. No entanto, a França como um todo constitui uma CF, pelos critérios já definidos. Além da França, também na Guiné-Bissau são faladas mais de quinze 
línguas. Mesmo assim, ela constitui uma CF. Essa CF é independente da senegalesa, embora na região sul do Senegal (Casamansa) se fale também a língua mais falada na Guiné-Bissau, que é o crioulo português. O que acontece é que Guiné-Bissau e Casamansa constituem a CL do crioulo, mas não uma CF. Os casamansenses interagem muito mais com os restantes senegaleses do que com os guineenses, com os quais compartilham uma língua, portanto fazem parte da CF senegalesa. Como se vê, há CFs simples, como a islandesa, e CFs complexas ou multilíngües, como a guineense e a francesa.

Portanto, uma CF existe em um território delimitado geográfica e politicamente, no seio do qual a interação tem que se dar de alguma maneira. A divisão política e o desejo de constituir uma nação unificada ou um grupo com identidade própria dão lugar a todo um conjunto de meios de comunicação que opõe essa CF às outras. Tudo isso opõe a Suíça à França, apesar de grande parte do território suíço ser de língua francesa.

Do que acabamos de ver, podemos dizer com toda certeza que a Guiné-Bissau constitui uma CF. Apesar de seu multilingüismo e sua multietnicidade, apesar de seu território ter sido delimitado artificialmente no final do século passado (Conferência de Berlim em 1884-1885, Acordo Franco-Português em 1886), podemos considerar esse país como uma CF. Com efeito, não se conhece nenhum caso de algum guineense que não tenha conseguido se comunicar (trocar atos de fala) com qualquer outro guineense por falta de uma língua comum. Além disso, temos o crioulo, cujo domínio aumenta dia a dia. Hoje podemos afirmar que praticamente todo guineense tem pelo menos um domínio passivo dele.

Se nas CFs homogêneas, como a islandesa, há muita variação lingüística, que dizer das heterogêneas e das línguas que as integram, como é o caso da Guiné-Bissau. A língua principal desse país, o crioulo, apresenta muita variação, devido ao fato de integrar (nos dois sentidos da palavra) uma CF tão heterogênea, complexa e multilíngüe como vimos. 
CL pode ter um domínio geográfico maior, como o do inglês, ou menor, como o do islandês. CF, por outro lado, pode ser simples (homogênea) ou complexa (heterogênea), sendo que a maioria é complexa, como já sabemos. O ideal seria que CL e CF coincidissem, como no caso islandês e de algumas línguas ameríndias, mas isso raramente acontece. Os casos em que um povo é o único falante de sua língua e vive em seu próprio território são a exceção, não a regra. O normal é haver mais de uma língua em determinado território (CF complexa) e cada língua ser falada em mais de um território, portanto fazer parte de mais de uma CL.

Retomemos a CF guineense e examinemos mais microscopicamente sua composição. No seio dessa comunidade, há subcomunidades, representantes de outras CL. As principais são fula, balanta, mandinga, manjaco, pepel, felupe, beafada, bijagó, mancanha e nalu. Todas essas CL vão muito além das fronteiras guineenses. Por exemplo, o mandinga é mais falado nos países vizinhos do que na Guiné. Mas, no interior do país, há diversas minicomunidades, ou seja, mini-CF de cada uma delas, salpicadas aqui e ali, embora haja tendência a concentrarem-se em uma única área territorial. Até a CL portuguesa se faz presente no país, de modo que há uma sub-CF portuguesa também. A língua mais falada por mais de $80 \%$ da população é o crioulo, à vezes como $\mathrm{L} 1$, às vezes como $\mathrm{L} 2$. Como vimos, sua $\mathrm{CL}$ se estende até o sul do Senegal. Mas, na CF guineense, o crioulo é uma espécie de elo que une toda a grande variedade lingüística do país. Há ainda minicomunidades (CF) francesa, cassanga, wolof e outras. Portanto, a guineense é uma das CF mais complexas do mundo. Talvez a única mais complexa do que ela seja a da Papua-Nova Guiné, em que o crioulo tok pisin tem um papel aglutinador semelhante ao do crioulo português na Guiné-Bissau. Mas há diversos exemplos de CF relativamente pequenas. Algumas delas são constituídas de comunidades de imigrantes, como as diversas comunidades de alemães do sul do Brasil e de japoneses de São Paulo e Paraná.

Em geral, fala-se na comunidade dos surdos (CS) como se se tratasse de uma comunidade igual a qualquer outra. Se fosse assim, 
poderíamos falar em comunidade das mulheres, comunidade das crianças, comunidade das meninas, comunidade dos meninos, comunidade dos jovens, comunidade dos velhos e assim ad infinitum. Certamente, o que se tem chamado de comunidade não pode ser isso. Como vimos, os membros da comunidade de surdos se dispersam pelo $\mathrm{T}$ da(s) língua(s) dos ouvintes da comunidade maior a que pertencem. No entanto, a distinção recém-apresentada entre CL e CF nos permite entender o que se passa com a CS.

Que as línguas de sinais (ou gestuais) são línguas naturais, não resta a menor dúvida. Isso já as distingue das línguas artificiais, como o esperanto, o volapük e outras. No entanto, elas não se enquadram plenamente na EFL, pelo fato de, como afirmou Mottez, sua CL não ter um T próprio. Por isso, sua CL não é uma CL prototípica. O que elas têm são comunidades de fala. Qual é, então, a CF no caso das línguas de sinais? Trata-se das sociedades ou associações locais, onde os cidadãos surdos se reúnem para trocar idéias, para contar piadas, enfim, para conviver. Essas sociedades ou associações funcionam como CF para os surdos, no verdadeiro sentido de Interaktionsgemeinschaft e de Kommunikationsgemeinschaft. Sua CL, como já vimos, dispersa-se por todo o território da comunidade a que pertencem suas famílias. Tanto a CL quanto a CF dos surdos se constitui de uma mistura de pessoas de todos os segmentos da sociedade, tanto socioeconômico quanto racial.

No caso do Brasil, a CL dos surdos é constituída por todos os cidadãos surdos que se espalham pelo país e que dominam o sistema da língua brasileira de sinais, também conhecida por LIBRAS. Quanto à $\mathrm{CF}$, como acabamos de ver, não é só uma, são diversas. Existem tantas CFs de surdos no Brasil quantas forem as associações de surdos locais. Portanto, como faz o ecólogo, também o lingüista que for estudar o uso de LS tem que fazer um recorte e determinar que associação vai investigar. Nessa perspectiva, é importante saber que, devido à origem e condição social diversas de cada membro de cada CF, há muita variedade no que se refere ao nível de línguagem que dominam. Uns têm mais sinais domésticos, outros menos. Alguns podem ter noção de outras línguas de sinais, como a americana. 
Alguns praticam datilologia mais, outros menos. Alguns são mais influenciados pelo português escrito e até oralizam mais, outros menos, e assim por diante.

As associações de surdos são CFs semelhantes às colônias de imigrantes. Por exemplo, os caboverdianos imigrados em Boston se reúnem na sede da associação deles na região para falar de sua terra natal, de suas tradições, da família que deixaram em Cabo Verde, entre outros assuntos. Tudo se passa em crioulo. Terminadas as reuniões, cada um vai cuidar de sua vida, geralmente falando inglês, pois estão dispersos na comunidade americana. Como vimos, é exatamente isso que ocorre nas associações de surdos. O equivalente a T em ambos os casos são as associações em que seus membros se reúnem. Os caboverdianos de Boston têm, adicionalmente, o T original Cabo Verde que, como CL, abrange sua CF, servindo assim de referência maior para eles. Os surdos contam apenas com as associações. Sua CL é sempre dispersa.

\section{A COMUNIDADE DE SURDOS}

Acabamos de ver que existem comunidades ouvintes e comunidades surdas. Vimos que os dois tipos de comunidade podem ser encarados tanto da perspectiva da comunidade de língua como da comunidade de fala. Entretanto, vimos também que a CL surda é fluida, dispersando-se pela CL da(s) comunidade(s) de ouvintes. Apesar disso, se os estudiosos das línguas de ouvintes geralmente não fazem distinção entre CL e CF, tampouco a fazem os estudiosos de línguas de sinais. No entanto, como tentei demonstrar, a distinção parece indispensável para um melhor entendimento tanto de um quanto do outro tipo de língua. Pelo fato de as línguas de sinais serem línguas naturais, manifestação da faculdade de linguagem do ser humano, o que vale para as línguas orais, em princípio, vale também para elas. Nesta seção, gostaria de discutir um pouco mais pormenorizadamente a situação das comunidades de surdos, com as respectivas CLs e CFs. 
Até autores gerativistas têm argumentado que "em qualquer região do mundo em que haja um grupo de surdos interagindo, existe uma língua de sinais rica e gramaticalmente complexa distinta da língua falada ao seu redor (e que é também estruturalmente distinta e mutuamente ininteligível com línguas de sinais de outras regiões)" (NEWPORT, 1999, p. 162). Essa argumentação vale igualmente para os ouvintes, como as línguas crioulas e os pidgins o demonstram. Isso acontece porque, como fica claro na EFL, língua é elemento do conjunto chamado comunidade. Não pode haver a parte sem haver o todo.

O que Newport disse ficou muito bem demonstrado na Nicarágua, como se pode ver em Kegl, Senghas e Coppola (1999). Certamente sempre houve sinais domésticos (mímicas) no país, mas seus usuários só conseguiram compor algum tipo de língua quando se juntaram em escolas na virada dos anos 70 para os 80 do século passado. Desse contato, surgiu a lenguaje de señas nicaragüense (LSN), algo como um pidgin que os surdos usavam para a intercomunicação entre si. Assim que crianças começaram a nascer nesse contexto, formaram uma língua plena, chamada idioma de señas nicaragüense (ISN), que continua em uso e sendo aprendida por novos ádvenas. Mas há uma outra variedade de língua de sinais em uso no país. Trata-se do pidgin de señas nicaragüense (PSN), usado para a comunicação entre falantes de espanhol, de um lado, e usuários de sinais, de outro lado, ou seja, os usuários de sinais domésticos, de LSN e de ISN.

Assim, há duas variedades pidginizadas dessas línguas. A primeira é a LSN, usada entre os falantes do "substrato", ou seja, dos sinais domésticos entre si. A segunda é o PSN, usado entre falantes de espanhol e usuários de sinais, seja lá em que categoria eles se enquadrem. Para o crioulista, trata-se de um cenário muito interessante. Foi justamente nesse contexto que as autoras escreveram o ensaio. Mas o mais importante é a própria emergência de uma língua onde não existia nenhuma antes.

Devo notar, no entanto, que nem sempre o resultado é o mesmo. Vejamos o que se passou na ilha colombiana de Providência. 
Sua população é de apenas 2.500 habitantes, mas há uma grande quantidade de surdos. Cada indivíduo surdo local desenvolveu algum tipo de sinais domésticos, muitas gerações atrás. Nessas condições, seria de se esperar que tivesse surgido uma língua de sinais plena, como são a LIBRAS, a American Sign Language (ASL), a língua gestual portuguesa (LGP) e diversas outras. No entanto, não foi o que aconteceu. A razão é que os ouvintes, freqüentemente familiares, assumem uma atitude paternalista em relação aos surdos, tratando-os como crianças. Por esse motivo, na maior parte das vezes, os surdos ficam fora das conversações. Mesmo quando se manifestam, um ouvinte logo interpreta oralmente o que acha que o surdo quis dizer. Às vezes, nem espera o surdo terminar seu enunciado. Pelo fato de os surdos serem tratados quase como incapazes, eles sequer se juntam entre si, em grupos, embora haja alguma coisa em comum entre as diversas manifestações individuais de gestos domésticos. $\mathrm{O}$ conjunto dessas manifestações individuais seria, no máximo, uma língua subdesenvolvida, segundo Washabaugh (1991), de onde tirei essas informações. Seria algo próximo ao pidgin instável ou jargão do período inicial do contato de falantes de línguas mutuamente ininteligíveis.

Da perspectiva da EFL, o que aconteceu e acontece na Ilha de Providência é facilmente explicável. Uma vez que os surdos não têm chance de se expressar, além de serem tratados como seres infantis, não tiveram oportunidade de formar CFs (associações). Como não se formou nenhuma CF, a CL ficou inviabilizada. Historicamente, a língua sempre surge de atos de fala concretos, conforme Saussure afirmara e Newport mostrou. A conclusão de Washabaugh é que a criação de uma língua não é apenas uma atividade cerebral mas, antes de tudo, uma construção que depende de condições sociais específicas.

O nível de proficiência na LS varia muito de indivíduo para indivíduo, o que se deve, sobretudo, ao modo pelo qual a língua foi adquirida e às condições de praticá-la. Como disse Newport, 
devido à variedade de causas genéticas da surdez, a maioria das crianças (90\%) nascem em famílias ouvintes em que ninguém usa sinais; apenas 5\% das crianças surdas nascem em famílias com pais surdos onde, portanto, há uma língua de sinais desde o nascimento.

Ela acrescenta que "os 5\% restantes de crianças surdas têm apenas a mãe ou o pai surdo" (p. 162). Finaliza dizendo que "apenas uma ínfima percentagem de membros da comunidade surda adquiriu a língua de sinais pela aquisição nativa de um estímulo lingüístico nativo" (p. 163). Mas os problemas das comunidades de surdos não param por aí.

Já vimos que a composição socioeconômica e étnica da comunidade surda é a mais variada possível. Por isso, o que determina a filiação de um surdo a uma comunidade surda é pura e simplesmente o fato de ser surdo e de geralmente usar a língua de sinais. Poder-se-ia alegar que as comunidades de ouvintes também são heterogêneas. De fato, elas o são. No entanto, há uma tendência de seus membros se reunirem apenas em grupos de interesse, havendo até uma certa tendência a separações étnicas, como no caso das "colônias" de imigrantes que constituem enclaves em uma comunidade maior. Isso quer dizer que os equivalentes aos ouvintes das CFs surdas, ou seja, os clubes, geralmente são freqüentados por indivíduos que têm muito em comum socioeconômica e etnicamente.

Quando se fala em comunidade surda, parece que isso implica que só há surdos na comunidade. Não é bem o que acontece. Na verdade, das comunidades surdas geralmente fazem parte, além dos próprios surdos, motivo principal da própria existência da sociedade, parentes, profissionais ou ainda surdos que vêm de outros lugares e que ainda não aprenderam toda a L da comunidade. Por exemplo, a comunidade de surdos de Prata (MG) está se formando ainda. Por isso, em seu seio há diversas pessoas ouvintes (ALMEIDA, 2003a).

Além de a CL surda ser dispersa, o contato de cada surdo no seio da CF tem um caráter intermitente. Isso significa que os surdos não passam o dia todo e todos os dias em sua associação. Cada um deles vai para lá para o seu convívio social, para conviver com seus 
wantok, termo do crioulo tok pisin que significa "aqueles que têm a mesma língua”. Em geral, isso se dá à noite, ou nos fins-de-semana, ou feriados, isto é, nos dias em que não têm que trabalhar. No trabalho, geralmente convivem com aloglotas ou com pessoas cuja língua eles só dominam como L2. Tudo isso visa a mostrar o quanto a vida social do surdo é difícil, como veremos mais detalhadamente na seção 5.

Quando se fala em comunidade de surdos, é preciso reiterar que seus membros não são indivíduos de $\mathrm{P}$ que convivam em um T específico. Vimos que, da perspectiva de CL, seus membros se pulverizam por diversos pontos do $\mathrm{T}$, inseridos em famílias freqüentemente ouvintes, e com poucas oportunidades de interagirem entre si. O que existe de modo mais facilmente discernível em termos de comunidade de surdos são as diversas CFs, que se manifestam nas associações em que os surdos se reúnem.

A CL surda é uma CL ganglionar. Mas o importante a frisar é que as línguas de sinais não infringem a EFL. O único problema é que a atendem plenamente apenas da perspectiva de CF. Tanto que, nos casos em que isso não se deu, como na Ilha de Providência, não chegou a se formar uma língua.

\section{COMUNIDADE E IDENTIDADE INDIVIDUAL}

Na vida prática do indivíduo surdo, a existência da CL não significa muita coisa. Para ele, o que interessa mesmo é a sua pequena CF. A CL pode interessar como referência maior, apenas para saber que faz parte de um universo mais amplo, ao qual eventualmente pode se referir. É o domínio do sistema lingüístico da língua de sinais, motivo pelo qual ela só existe para ele in potentia, ao passo que a CF existe in acto. É na CF que ele pode encontrar seus wantok ou, mais genericamente, seus pares. A identidade surda reside tanto na CL quanto na CF, mas, concretamente, o surdo só verifica o fato na $\mathrm{CF}$, onde se encontra com pessoas de carne e osso, que têm os mesmos problemas que ele. 
É na CF que os surdos se sentem em comunhão, que, como definida em Couto $(1999,2002)$, é uma espécie de pré-requisito para atos de interação comunicativa, nos termos de Malinowski (1972) e de Jakobson (1969). Sempre que algumas pessoas estão juntas, há comunhão se houver uma satisfação com o próprio fato de estarem juntas, mesmo não havendo nenhuma novidade para ser transmitida. Se houver, tanto melhor, todas estão receptivas e até ávidas por novidades. Se não houver, não importa. O que importa é o estar junto, falando sobre frivolidades, contando piadas, enfim, simplesmente em comunhão, como o termo religioso já dá a entender. Aliás, Fill (1993) afirma que essa é a principal função da língua, não a transmissão de informação.

Widell (1992) conta que, já no século XIX, na Dinamarca "os membros da comunidade dos surdos viviam expostos à sorte e tinham sorte o suficiente de ter amigos na associação dos surdosmudos para consolá-los e encorajá-los nos altos e baixos da vida". É quase certo que, desde que o mundo é mundo, os indivíduos surdos se sintam entre os ouvintes exatamente como nós nos sentimos quando estamos em um país estrangeiro cuja língua desconhecemos. Podemos até reconhecer o ambiente natural e o construído, as ruas, enfim, todo o ambiente e, inclusive, decodificar os cartazes e as placas. Entretanto, a impossibilidade de nos comunicarmos com as pessoas nos deixa como que impotentes.

Já vimos que a identidade de qualquer indivíduo se estabelece por sua inserção tanto na comunidade de língua como na comunidade de fala. Vimos também que, para o surdo, é na comunidade de fala que isso se implementa praticamente. No entanto, para os ouvintes não é muito diferente. Quando estou em um país cuja língua desconheço e encontro alguém que estudou português (domina o seu sistema, mas não pertence à comunidade de língua portuguesa), começo a me identificar com ele. Se encontro com um português nesse mesmo país, sinto que me idenfico com ele ainda mais, pois pertencemos à mesma comunidade de língua. Se estou, porém, em Portugal e encontro um brasileiro, sinto mais identidade ainda com 
ele. Isso ocorre não só porque compartilhamos o sistema da língua portuguesa (pertencemos à mesma comunidade de língua), mas também porque pertencemos à mesma comunidade de fala.

As pessoas surdas se vêem como uma minoria, cultural e lingüística. Minoria porque fazem parte da comunidade surda, cuja CL está pulverizada no território de uma comunidade maior, dominante. Sua CF é muito pequena, se comparada à CF em que os ouvintes atuam. Além do mais, sua CF é um pequeno enclave no território da CL ouvinte e, o que é pior, distribuída de forma ganglionar por ela. Por isso, os surdos sempre se sentiram diferentes das pessoas ouvintes e instintivamente sentem-se parte da comunidade surda que tem a sua própria língua para comunicar. Uma comunidade onde não ser capaz de ouvir ou falar não é visto como um problema. $\mathrm{Na}$ comunidade surda, as pessoas são todas iguais, no sentido de falarem a mesma língua, de serem todos wantok.

Isso não acontece plenamente no seio da família, motivo pelo qual os surdos encontram sua verdadeira identidade social na comunidade de surdos (CF). Na familia, sua identidade é mais biológica do que social, ou seja, no seu seio, cada surdo é filho(a), pai/mãe, irmã(o) e assim por diante. Tanto que quase todo surdo reclama que os parentes ouvintes discutem, riem de diversos fatos sobre os quais eles nada sabem. O que é pior, freqüentemente, esses parentes não têm paciência para traduzir tudo para a língua de sinais para eles.

Devido a esses e outros problemas, como a discriminação e a introjeção de que são mal vistos pela sociedade, alguns surdos renegam sua qualidade de surdez, tentando passar-se por ouvinte ou, pelo menos, considerando o grupo de surdos como "os outros", "eles", e não "nós". Oralizam o máximo que podem, a despeito das limitações desse modo de comunicar. Botelho (1999) apresenta diversos casos de surdos que não se identificam com a comunidade surda. Uma entre eles, que oralizava, considerava-se como uma espécie de embaixadora do grupo, mas sem ser membro dele, mesmo trabalhando em seu seio. 
O que interessa para o surdo como ser humano, como cidadão, é a identidade social, que ele encontra na CF surda. Encontrando a identidade, acaba vendo sua auto-estima ser elevada. A elevação da auto-estima resulta em maior dignidade como cidadão e alegria de viver. Botelho (1999) conta o caso de Denise, que assimilou bem o uso de LIBRAS. Após se enturmar com os outros surdos, mudou o modo de "vestir-se e de portar-se. Conversava mais desembaraçadamente, a língua de sinais havia melhorado consideravelmente, diferente das primeiras entrevistas, quando era mais contida, tímida e pouco expressiva" (p. 161).

O indivíduo só é ele próprio se projetado no outro; a imagem que os outros têm dele pode influenciar sua identidade e, conseqüentemente, determinar o grau de auto-estima. No caso, "o outro" é cada indivíduo da CF surda. É nela que os surdos se sentem seres humanos e cidadãos plenos. Vários outros exemplos poderiam ser aduzidos, como o do senhor Wilson, da comunidade de surdos de Prata. Ele "se sentia mais à vontade e alegre entre os surdos do que na festa de seu filho" (ALMEIDA, 2003b).

O fator determinante da identidade de um membro de qualquer comunidade é a língua. No caso da comunidade surda, isso tem um peso ainda maior, pois, se a excluirmos, o que resta é um fator médico negativo, ou seja, a ausência da audição de seus membros. Essa ausência acaba levando a uma concepção de deficiência (BEHARES, 1999). Portanto, é melhor enfatizar o fator positivo língua como elemento agregador dos cidadãos surdos. Do contrário, haveria também o problema da diversidade socioeconômica e étnica de cada membro, o que tenderia a dividi-los, não a unilos. A LS é um fator de identidade não apenas individual, mas também da comunidade. A tal ponto a língua de sinais é importante para a comunidade surda que se poderia chamá-la de comunidade de lingua de sinais (CLS), ou seja, usar a língua como ponto de partida para caracterizar a comunidade.

Eu conheci surdos em diversas situações. Os que viviam isolados eram irrequietos, irritadiços e até agressivos. Os que faziam 
parte de alguma CF e, portanto, de uma CL maior, demonstravam estar de bem com a vida, mesmo quando se encontravam fora desse meio. Geralmente já dominavam a LIBRAS, além do português sinalizado, e até vocalizavam o português razoavelmente. Enfim, eram pessoas que tinham uma multicompetência lingüística, mas, como base fundamental, a língua de sinais. Eram cidadãos felizes porque encontraram sua identidade na comunidade surda, efetivamente na comunidade de fala surda.

\section{OBSERVAÇÕES FINAIS}

As bases epistemológicas da ecologia prevêem que é o estudioso que delimita o seu objeto. Ele tem que fazer um recorte no continuum que é a realidade dos ecossistemas, a fim de delimitar o que vai estudar. Isso vale também para as ciências humanas. Não há limites claramente estabelecidos entre as diversas populações que habitam determinada região do mundo, uma vez que os agrupamentos humanos freqüentemente se sobrepõem. Tampouco existem limites claros entre as línguas. O dialetólogos do século XIX já sabiam que era difícil dizer-se "aqui termina o francês" e "aqui começa o italiano". O que há é uma diferenciação gradativa, que parte de determinado centro, por exemplo, Paris, e vai até ao limite extremo da periferia, próximo à fronteira. O único lugar em que se tem certeza de que começou o italiano é a próxima cidade Itália adentro.

O mesmo tipo de problema é confrontado pelo estudioso de línguas de sinais. Ele delimita um agrupamento de pessoas e fixa esse agrupamento como a comunidade (CF) que vai estudar. Se tal agrupamento está vinculado a uma associação, as coisas ficam mais fáceis. Em caso contrário, a tarefa do investigador fica mais complicada. É o que acontece na Ilha de Providência e na cidade de Prata. Da primeira já falei rapidamente. Na segunda, até o ano de 2002 (ano de fundação de sua associação), os surdos e surdos-cegos locais viviam relativamente dispersos, sem um contato sistemático uns com os outros, embora sempre inventassem pretextos para se 
encontrar, como festas, comemorações, etc. Portanto, quando se falava na comunidade surda de Prata, estava-se referindo aos diversos indivíduos surdos que habitavam a cidade, mas vivendo cada um deles em suas respectivas casas e, freqüentemente, sem contato uns com os outros. Alguns usam sinais domésticos, outros têm rudimentos de LIBRAS. Uns tentam oralizar, outros tentam juntar as duas coisas. Logo, no sentido em que o conceito foi definido anteriormente, não se poderia ainda falar em "comunidade de surdos de Prata" (ALMEIDA, 2003a, b), mas em conjunto de surdos de Prata, exatamente como se deveria falar em conjunto de surdos da Ilha de Providência. Em ambos casos, os surdos e/ou surdos-cegos estão dispersos, não se agregaram em uma associação a fim de entrar em comunhão e falar sobre a chuva e o bom tempo. Se isso acontecesse, certamente formariam uma língua própria.

A questão do espaço foi tratada apenas no que tange ao $\mathrm{T}$ da CL. Mas ele é importante também para os atos de fala, pois, ecologicamente, dois indivíduos só podem interagir comunicativamente se estão espacialmente próximos. Isso se torna mais importante no caso das comunidades surdas. Nas CFs de ouvintes, há muito tempo se podem trocar atos de interação comunicativa a distância, facultados pela tecnologia. Nas CFs de surdos, pode ser que isso já exista também (telefone visual?), mas, de qualquer maneira, não é tão generalizado como o telefone, e outros meios de comunicação a distância à disposição dos ouvintes. A interação entre indivíduos surdos ainda tem que se dar precipuamente entre indivíduos que estejam espacialmente próximos. A despeito dos canais derivados de contato entre emissor e receptor, o canal original e fundacional é o da co-presença física dos interlocutores, tanto para surdos quanto para ouvintes. Trocado em miúdos, o T é importante também da perspectiva da CF porque o T é concreto, é o espaço físico do edifício (um salão, por exemplo) em que se encontra a associação na qual os surdos se reúnem.

Se o espaço é importante para que haja atos de interação comunicativa entre emissor e receptor, o reverso também é válido. 
Dois indivíduos que estejam juntos, normalmente interagem comunicativamente. Se pertencem também à mesma CL, isto é, se dominam a mesma língua, isso se dá de forma normal. Se não têm língua comum, tentam forjar uma. É o que se dá nos casos de pidginização e crioulização, em que falantes de várias línguas mutuamente ininteligíveis se vêem em contato em determinado território. O pidgin e o crioulo são a resposta que a situação dá ao problema. Algo parecido se deu com os surdos da Nicarágua (KEGL; SENGHAS; COPPOLA, 1999). A contraprova são os surdos da Ilha de Providência. É o espaço físico que permite indivíduos se juntarem e interagirem. Dessa interação pode consolidar-se um meio de comunicação. Esse meio de comunicação só se consolidará caso se consolide uma comunidade. Isso significa que um meio de comunicação (língua) só emergirá simultaneamente ao surgimento de uma EFL, da qual faça parte. É o espaço que permite o surgimento de um ecossitema, que pode levar a uma comunidade clímax.

Diante de tudo que acaba de ser dito, conclui-se que as comunidades surdas são verdadeiros laboratórios para se estudar a Ecologia Fundamental da Língua e todas as suas implicações. Dito de outro modo, tanto as comunidades surdas quanto as línguas dos surdos são laboratórios para se estudar a natureza da sociedade e da linguagem humanas. Acima de tudo, o surgimento e a existência das línguas de sinais falam a favor da tese de que a língua é antes de tudo um meio de comunicação, embora seja também um dom biológico transmitido hereditariamente. Uma língua só surge quando e onde há necessidade dela para a interação entre seres humanos. Do contrário, não surgirá. Em síntese, é a necessidade de comunicação, provocada pela convivência em um mesmo espaço, que faz surgir uma língua.

\section{NOTA}

* Este texto foi apresentado no "Simpósio Internacional: Do Gesto à Escrita num Contexto Bilingue de Educação da Pessoa Surda”, na Faculdade de Psicologia da Universidade de Lisboa, em 2 de maio de 2003. 


\section{REFERÊNCIAS BIBLIOGRÁFICAS}

ALMEIDA, Célia Aparecida Faria. Aspectos fonológicos da produção sonora em português de um surdo nato. Monografia. Universidade de Brasília, 2002.

- A comunicação entre membros de um grupo de surdocegos de Prata (MG). Papia 13, p. 210-215, 2003 a.

. A variação lingüística na comunidade de surdos e surdocegos de Prata (MG). Monografia. Universidade de Brasília, 2003b.

BASTARDAS I BOADAS, Albert. Biological and linguistic diversity: Transdisciplinary explorations for a socioecology of languages. DiversCite VII, 2002. Disponível em: <www.telug.uquebec.ca/diverscity/SecArtic/Arts/2002/bastarda/txt.htm>. Acesso em: 2002.

BEHARES, Luís. Línguas e identificações: as crianças surdas entre o 'sim' e o 'não'. In: SKLIAR (Org.). p. 131-147, $1999 .$.

BLOOMFIELD, Leonard. Language. New York: Holt, Rinehart \& Winston, 1933.

BOTELHO, Paula. Surdos oralizados e identidades surdas. In: Skliar (Org.). p. 149-164, 1999.

COUTO, Hildo Honório do. Le créole guinéen et ses relations avec le portugais et les langues africaines. Etudes créoles XIII,1, p. 35-44, 1990.

48, 1991.

. Unidade vs. diversidade lingüística na Guiné-Bissau. Papia I, 2, p. 42-

. O crioulo português da Guiné-Bissau. Hamburgo: Helmut Buske Verlag, 1994. UnB, 1996.

Introdução ao estudo das linguas crioulas e pidgins. Brasília: Editora da

. Contato interlingüístico: da interação à gramática. Disponível em: <http:/ /www.unb.br/il/let/crioul/contato.htm>, 1999. Acesso em: 2002.

. Multilingüismo e contato de línguas. Gragoatá 9, p.29-43, 2000.

. Anti-crioulo: manifestação lingüística de resistência cultural. Brasília: Thesaurus, 2002a.

. A lingua franca mediterrânea. Brasília: Oficina Editorial do IL e Plano Editora, 2002b.

- Aquisição de L1 por Aninha: uma visão ecológico-interacional. Revista

Planalto 1: Lingüística, p. 6-54, 2002c. 
COUTO, Hildo Honório do; SILVA, Denize E. G. da. Repetição e reduplicação em língua franca. Papia 11, p. 18-26, 2001.

DeGRAFF, Michel. Language creation and language change: creolization, diachrony, and development. Cambridge, Mass.: The MIT Press, 1999.

ECO, Umberto. A estrutura ausente. 2. ed. São Paulo: Editora Perspectiva, 1974.

FILL, Alwin. Ökolinguistik. Tübingen: Gunter Narr Verlag, 1993.

GUMPERZ, John. Speech community. In: GIGLIOLI, Pier Paolo (Org.). Language and social context. Harmondsworth: Penguin Books, 1972. p. 219-231.

JAKOBSON, Roman. Lingüística e poética. Lingüistica e comunicação. São Paulo: Cultrix, 1969. p. 118-162.

KEGL, Judy; SENGHAS, Ann; COPPOLA, Marie. Creation through contact: sign language emergence and sign language change in Nicaragua. In: DeGRAFF (Org.). Language creation and language change: creolization, diachrony, and development. Cambridge, Mass.: The MIT Press, 1999. p. 179-237.

LABOV, William. Is there a creole speech community? In: VALDMAN, A.; HIGHFIELD, A. (Org.). Theoretical orientations in creole studies. N. York: Academic Press, 1980. p. 369-388.

MALINOWSKI, Bronislaw. O problema do significado em linguagens primitivas. In: ODGEN, C. K.; RICHARDS, I. A. O significado de significado. Rio de Janeiro: Zahar Editores, 1972. p. 295-330.

MORGAN, Lweis H. Ancient society. New York: Henry Holt and Company, 1878.

MOTTEZ, Bernard. Los banquetes de sordomudos y el nacimiento del movimiento sordo. GELES 6, 5, p. 5-19, 1992.

MUFWENE, Salikoko. The Ecology of Language Evolution. Cambridge University Press, 2001.

MÜHLHÄUSLER, Peter. Languagage and environment - Environment of language: A course in ecolinguistics. Londres: Battlebridge, 2003.

NEWPORT, Elissa L. Reduced input in the acquisition of signe languages: contributions to the study of creolization. In: DeGRAFF (Org.). Language creation and language change: creolization, diachrony, and development. Cambridge, Mass.: The MIT Press, 1999. p. 161-178.

PENG, Fred C. C. Historical linguistics and sign language. The seventh LACUS Forum. Columbia, S.C.: Hornbeam Press, 1981. p. 388-398. 
SAUSSURE, Ferdinand de. Curso de lingüística geral. 5. ed. brasileira. São Paulo: Editora Cultrix, 1973.

SIPLE, Patricia. Understanding language through sign language research. New York: Academic Press, 1978.

SKLIAR, Carlos (Org.). Atualidade da educação bilingüe para surdos. Porto Alegre: Editora Mediação, 1999. p. 131-164.

TONNEAU, J. Sociologie économique. In: LEMONNYER, A. et al. Précis de sociologie. Marselha: Editions Publiroc, 1934. p. 93-147.

WASHABAUGH, William. Providence Island Sign Language: Laboratories and knowledge. Disponível em: <http:/www.uwm.edu/People/wash/prov.htm> (1991). Acesso em: 2002.

WIDELL, Jonna. A cultura surda dinamarquesa. GELES 6, 5, p. 20-49, 1992. 